\title{
Involvering øker motivasjonen til å delta i undervisningen
}

For å videreutvikle undervisning og samhandlingstrening i

voldsrisikohåndtering har man fått deltakerne til å medvirke. Dette har vist seg å øke motivasjonen til helsepersonell.

\section{Forfatter}

Toril Garborg

Miljøterapeut

Regional sikkerhetsseksjon, Dikemark sykehus og Oslo universitetssykehus Ullevål

Samhandling

Brukermedvirkning

Aksjonsforskning

Helsepersonell

Psykisk helse

Sykepleien 2019 107(74682)(e-74682)

DOI: https://doi.org/10.4220/Sykepleiens.2019.74682

\section{Hovedbudskap}

Denne artikkelen viser hvordan deltakermedvirkning blant helsepersonell kan bidra til at opplæringen oppleves som relevant og meningsfull. Deltakerne har medvirket i et aksjonsforskningsprosjekt for å videreutvikle undervisning og samhandlingstrening $\mathrm{i}$ voldsrisikohåndtering ved Regional sikkerhetsseksjon (RSA).

RSA er en høyspesialisert seksjon med regional funksjon for Helse Sør-Øst. Ved Dikemark har RSA tre kliniske enheter som mottar pasienter med alvorlige sinnslidelser og alvorlig voldsatferd til utredning og behandling. 
For å møte pasientene med felles holdninger med hensyn til behandling og omsorg, og samtidig ivareta sikkerheten både for pasienter og personalet, er undervisning i voldsrisikohåndtering en avgjørende faktor.

Miljøpersonalet på RSA har ukentlig undervisning og samhandlingstrening. Her trener de på autentiske utageringssituasjoner for å øke sikkerheten og tryggheten i situasjoner med utagerende pasienter. Undervisningen består først og fremst av samhandlingstrening, hvor det legges stor vekt på kommunikasjon med pasienter, å oppdage forvarsler på voldsrisikoatferd, tidlig intervenering for å unngå utagering, deeskalering ved aggressivitet, etikk og holdninger, ransaking og tvangsmiddelbruk som fysisk holding og beltelegging.

Psykiatriske sykepleiere har en sentral rolle i utvikling og gjennomføring av den simuleringsbaserte undervisningen og treningen (1).

\section{Omfanget av vold og utagering}

I Norge er ansatte i helse- og sosialsektoren særlig utsatt for vold, noe som innebærer store utfordringer for arbeidsmiljøet. I 2005 kom voldsbegrepet inn i arbeidsmiljøloven for første gang, og vi fikk en presisering om at arbeidstaker - så langt det er mulig skal beskyttes mot vold og trusler (2). Noen arbeidsplasser har stort omfang av vold og utagering, og det er viktig at de ansatte får relevant opplæring og praktiske øvelser slik at de kan håndtere dette.

Opplæringen bør inneholde forståelse av vold og aggresjon som fenomen og praktiske øvelser i aggresjonsdempende kommunikasjon og fysisk håndtering. Flere offentlige virksomheter har egne opplæringsprogrammer for ansatte, og det finnes ulike tilbydere av kurs i håndtering av utfordrende atferd (3). 


\section{三 «Mange kviet seg for rollespill, og det var behov for å videreutvikle undervisningsmetodene.»}

\section{Miljøpersonalet ved RSA har hatt ukentlig}

undervisning i voldsrisikohåndtering i mange år. Tidligere foregikk undervisningen i avdelingens gymsal og hadde hovedvekt på rollespill, hvor deltakerne ble tildelt ulike roller og trente på kommunikasjon, samhandling og mekanisk bruk av tvangsmidler. Erfaringsmessig var personalet lite motivert for undervisningen. Mange kviet seg for rollespill, og det var behov for å videreutvikle undervisningsmetodene.

\section{Videreutvikle undervisningen}

I 2013 startet undervisningsgruppen ved RSA et aksjonsforskningsprosjekt med den hensikten å videreutvikle undervisningsmetodene i undervisningen og treningen. Instruktørene i undervisningsgruppen ved avdelingen består blant annet av godt erfarne psykiatriske sykepleiere.

Problemstillingen i prosjektet var: På hvilken måte kan undervisning og samhandlingstrening ved RSA videreutvikles slik at rollespill blir ufarliggjort og deltakerne opplever en relevant og meningsfylt opplæring i sitt kliniske arbeid med pasienter?

Min rolle som yrkespedagog var å lede aksjonsforskningsprosjektet. Jeg skulle legge til rette for videreutvikling av undervisningen gjennom systematisk utprøving av ulike tiltak (aksjoner), refleksjon over gjennomføringen og planlegging av nye tiltak. Det var fokus på deltakermedvirkning under hele prosjektet. Deltakerne førte logg etter undervisning, slik at deltakernes tanker, følelser og opplevelser ble synliggjort. Loggene ble brukt som data i prosjektet, og undervisningen ble justert gjennom tiltak (aksjoner) etter deltakernes ønsker og behov. 
Oslo universitetssykehus (OUS) har en simulerings- og treningsavdeling (SIM-Oslo), som fungerer som en opplæringsenhet. Her kan man trene på simulering av både medisinske og psykiatriske scenarioer, og det blir lagt vekt på pedagogiske metoder (1).

Instruktørene i undervisningsgruppa ved RSA deltok på kurs ved SIM-Oslo for å bli fasilitatorer, og modellen ble tilpasset vårt bruk. Underveis i prosjektet fikk undervisningen navnet SIMBA.

\section{Læring gjennom oppdagelser}

John Dewey er kjent for begrepet Learning by Doing. Hans opprinnelige formulering skal ha vært: Learn to Do by Knowing and to Know by Doing (4). Det kan tolkes som at aktivitet alene ikke er tilstrekkelig i en læringsprosess, men at vi lærer ved å oppdage sammenhengen mellom det vi gjør, og de konsekvensene det får.

Etienne Wenger beskriver hvordan læring er et spørsmål om engasjement, som er avhengig av en mulighet til aktiv deltakelse i et praksisfellesskap (5).

Og Patricia Brenner hevder at kyndige sykepleiere fortrinnsvis bør undervises induktivt ved å begynne med en klinisk situasjon for deretter å supplere med sin oppfattelse av situasjonen (6).

\section{三 «Deltakerne gjennomfører en praktisk samhandling for deretter å dele sine opplevelser.»}

Scenariotrening er en form for induktiv opplæring, hvor deltakerne i scenarioet først gjennomfører praktisk samhandling i en case for deretter å dele sine opplevelser. Læring skjer ved at deltakerne opplever at det de gjorde i scenarioet, får konsekvenser som de får mulighet til å reflektere over i en debrifing etterpå. 
Scenariotrening starter med at fasilitator for timen informerer deltakerne om læringsmål, hendelsesforløp og pasientbeskrivelse. Alle deltakere skal være seg selv på jobb som sykepleiere eller annet helsepersonell, i motsetning til tidligere da de fikk tildelt roller. Ansvarsvakt i scenarioet er alltid en sykepleier som også har ansvaret i avdelingen, og som fordeler oppgaver som ved en rapport. Den eneste som spiller en rolle, er markøren. Markøren spilles av en av instruktørene i undervisningsgruppa.

\section{Tar del i egen læring}

Etter scenarioet leder fasilitator en strukturert debrifing med faktafase, analysefase og anvendelsesfase. I faktafasen blir deltakerne enige om hva som faktisk skjedde. I analysefasen reflekterer deltakerne over hva den enkelte gjorde som var bra, hvilke vurderinger som ble gjort underveis, og hva som kunne vært gjort annerledes.

Det er fokus på mestring, og deltakerne får muligheten til å gi tilbakemelding anonymt i logg etter undervisningen. Det er avgjørende at deltakerne er aktive i egen læreprosess. De lærer best når de selv oppdager og blir utfordret. På denne måten blir de motivert til selv å finne løsninger. «Det er bare jeg som kan oppdage noe for meg», hevder Nils Magnar Grendstad (7).

Spetalen viser til Vygotskys «utviklingssone», der utvikling skjer gjennom læring. Her får den mindre erfarne hjelp til å løse problemer av den mer erfarne (8). Deltakerne i prosjektet var en blanding av erfarne og uerfarne sykepleiere, helsefagarbeidere og ufaglærte, der de erfarne veiledet de uerfarne underveis. Ved å bli sett og tatt på alvor vil de fleste oppleve at motivasjonen øker. 
Det er dessuten viktig at opplæringen føles virkelighetsnær for deltakerne (8). Scenarioene ble derfor utarbeidet etter deltakernes ønsker om å trene på ulike kliniske utfordringer de hadde i avdelingen. Det er nødvendig å føle et behov for det som skal læres, og at man opplever å være medansvarlig for læringen (5).

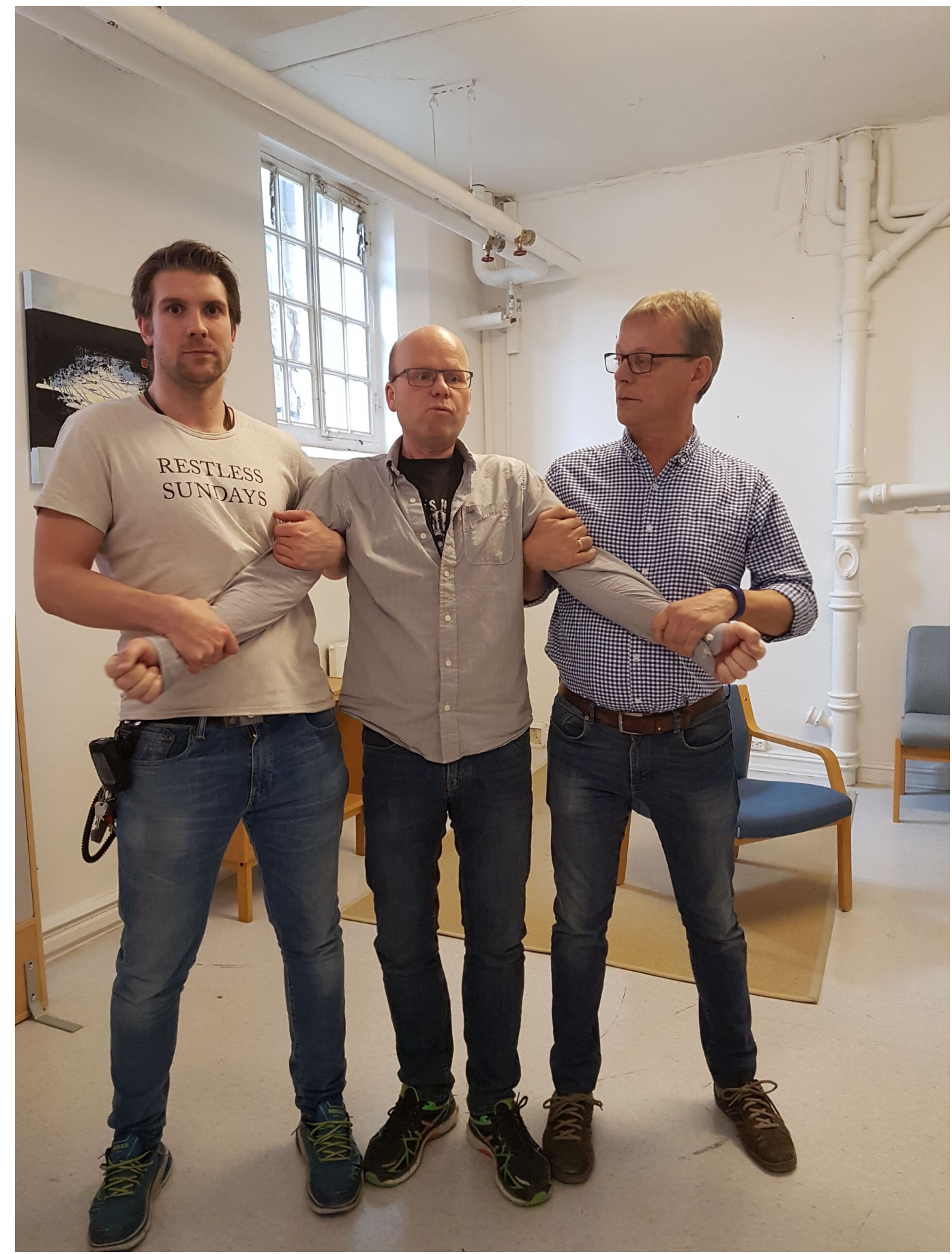

DELTAKERMEDVIRKNING: I undervisningen trener deltakerne på hvordan de skal håndtere utagerende pasienter. Her ved Regional sikkerhetsseksjon (RSA). 
I starten opplevde deltakerne det som utrygt å ha scenariotrening på tvers av enhetene ved avdelingen, og undervisningen ble derfor gjennomført i små grupper enhetsvis. På grunn av gjensidig beredskap på tvers av enhetene har avdelingen behov for at enhetene kan trene sammen. Så etter hvert som deltakerne ble tryggere på scenariotrening, ble enhetene blandet. Første forutsetning for at mennesker kan delta, er at en ikke er utrygg, passivisert eller undertrykt (9).

\section{Utvikle ny kunnskap}

Forskning og utviklingsarbeid er kreativ virksomhet som utføres systematisk for å få mer kunnskap, herunder kunnskap om mennesker, kultur og samfunn (10).

Aksjonsforskning er en form for forskning som utføres ved at den som forsker, er tett på virksomheten, eller området det forskes på. Aksjonsforskning er en metode som kan brukes til å utvikle ny kunnskap og en mulighet til å oppnå en kollektiv endring. Det å forske i egen praksis vil kunne tilføre egen arbeidsplass nytenkning gjennom å prøve ut ulike aksjoner (11).

Hans-Georg Gadamers tanker om forståelse er vesentlig i et aksjonsforskningsarbeid. Han mener at åpenhet er en forutsetning for å kunne hevde at man driver med forståelse (12). Fokuset i prosjektet var nettopp å være åpen for alle deltakernes opplevelser i undervisningen de deltok på. Fenomenologiske og hermeneutiske utfordringer ble tatt på alvor ved å ta den enkelte deltakers tanker, følelser og opplevelser på alvor.

\section{Fenomenologi}

Fenomenologi er læren om hvordan fenomener oppleves: At mine opplevelser er noe jeg vet best om selv, og jeg kan ikke være sikker på at andre oppfatter virkeligheten på samme måte som meg (13). 


\section{Hermeneutikk}

Hermeneutikk dreier seg om hva det vil si å forstå, og ifølge Hans-Georg Gadamer så begynner all forståelse med undring (12). Vi undrer oss over det vi står overfor, og vi undrer oss over om vi kan ha misforstått. Et fravær av en slik undring vil være til hinder for forståelse (13).

Fenomenologi er teorien om at mine opplevelser er noe jeg vet best om selv (13). Gjennom å ta den enkelte på alvor bidro vi til den enkeltes opplevelse av å bety noe. For å kunne gjennomføre prosjektet var alle deltakernes perspektiver viktige.

Undervisningen ble videreutviklet gjennom tiltak og handlinger (aksjoner). Hensikten var å forske sammen med alle deltakerne i prosjektet. Alle som deltok, ble utfordret til å komme til orde, og praksis ble produsert av deltakerne gjennom enighet om hva som var meningsfylt (5). Grunnstrukturen i aksjonsforskningsprosjektet så slik ut: avklaring av situasjonen nå - avklaring av ønsket situasjon utvikling av tiltak for å oppnå ønskesituasjonen gjennomføring av tiltak - refleksjon over gjennomføring - justering av fremtidige strategier som følge av det vi har lært (13).

\section{Strukturert logg}

Data ble samlet inn på en måte som i størst mulig grad ivaretok den enkelte deltakers forståelse av virkeligheten de befant seg i. Som et pedagogisk redskap var strukturert logg tenkt som et refleksjonsog læringsverktøy etter all undervisning. 
Det er avgjørende for læring at deltakerne aktivt deltar og blir engasjert i meningsfylt praksis som involverer aktivitet, diskusjon og refleksjon (5). Ved å skrive logg fikk deltakerne satt ord på egne reaksjoner og opplevelser relatert til undervisningen. Refleksjon er å ta ansvar for de fremtidige konsekvensene av nåtidens handlinger, og interesse utgjør den motiverende kraften i enhver erfaring som har et formål (14). Ved å bevisstgjøre deltakerne på egne ønsker og behov kunne undervisningen justeres i henhold til det deltakerne hadde behov for.

\section{Analyse av loggene}

Den kvalitative tilnærmingen har som mål å avdekke meninger og forståelse i spesifikke sammenhenger. Av den grunn kan det være lite fruktbart å bruke kvantitative vurderingskriterier på kvalitativ forskning (5). En grunntanke i aksjonsforskning er at man forsker sammen med og ikke på deltakere (13).

Det ble systematisk jobbet med deltakermedvirkning ved at data fra deltakernes logger jevnlig ble analysert. Videre ble undervisningen justert og videreutviklet gjennom nye tiltak i forbindelse med deltakernes tilbakemeldinger om ønsker og behov for undervisning. For å analysere data ble en variant av grounded theory benyttet.

\section{三 «Analysemetoden tar hensyn til enkeltindividene i fellesskapet.»}

Loggene ble sammenfattet og kopiert opp til alle i undervisningsgruppa, og alle merket seg det som kom til syne under gjennomlesing av loggene. Arbeidet ble validert ved at det samme kom til syne for flere.

Metoden er inspirert av Bruce McKenzie (15) og hans tro på «emergence», tilsynekomst. Analysemetoden tar hensyn til enkeltindividene i fellesskapet og viser hvordan en demokratisk analyseprosess kan konstrueres og som har til hensikt å bidra til at en form for gyldig fellesforståelse kan komme til syne (16). 
Kathy Charmaz har jobbet med å videreutvikle grounded theory. Hun oppfordrer til å samle mye data som ser det samme fenomenet fra ulike perspektiver.

Det er nettopp det med at noe kommer til syne, som er av betydning for Charmaz. Det skal utfordre oss til justeringer og nye veier (17).

\section{Innflytelse på egen opplæring}

I lys av det læringsteoretiske perspektivet kom det tydelig frem at deltakermedvirkning ga deltakerne innflytelse på egen opplæring. På denne måten opplevde de undervisningen som mer meningsfylt og relevant i sitt kliniske arbeid. Ved å bruke læringsmål og tid på refleksjon etter scenariotreningen, fikk deltakerne mulighet til å analysere og diskutere hva de gjorde bra, hvilke vurderinger de gjorde underveis, og hva de kunne gjort annerledes.

Analyse av logger viste at deltakerne opplevde undervisningen som mer lærerik og virkelighetsnær. Etter hvert som deltakerne ble tryggere på scenariotreningen, skrev blant annet deltakerne i loggene at undervisningen var «lærerik og virkelighetsnær», «mer realistisk enn før» og «lærte at jeg faktisk kan noe». Tilbakemeldingene viste at deltakerne opplevde undervisningen og samhandlingstreningen som nyttig. De opplevde å bli hørt. Og de fikk påvirke sin egen opplæring, noe som igjen ga motivasjon for deltakelse.

Å ta del i meningsfylte aktiviteter gir engasjement som bidrar til å danne praksisfellesskap, noe som igjen skaper engasjement og tilhørighet (5). Benner hevder at kyndige sykepleiere lærer best ved bruk av caser, og at sykepleiere på et kompetent nivå lærer mye ved å øve på planlegging og koordinering i rollespill (6).

\section{Diskusjon}


Alle instruktørene deltok i analysearbeidet gjennom hele prosjektet, og arbeidet ble validert ved at flere så det samme komme til syne til tross for at vi hadde forskjellig bakgrunn og forforståelse.

I startfasen av prosjektet var det søkelys på hvordan helsepersonell kunne motiveres til å delta på undervisningen. Dewey hevder at man i pedagogisk utvikling må ta hensyn til individets spesifikke ønsker og behov (14). For å oppleve at det vi gjør er meningsfylt, må vi aktivt delta for å finne mening, påvirke og bli påvirket og involvere deltakerne i handlinger, diskusjoner og refleksjoner som utgjør en forskjell (5).

Kredibilitet ble ivaretatt ved at det var deltakernes opplevelser som bidro til data (18). Validering fungerte som en kvalitetskontroll gjennom hele forskningsprosessen (19) ved at undervisningsgruppa jevnlig analyserte data og var opptatt av å avdekke mangfoldigheten i det som kom frem.

\section{三 «Man kan komme langt $\mathrm{i}$ en utviklingsprosess ved å involvere deltakerne.»}

Et aksjonsforskningsprosjekt starter alltid med et behov om å endre noe til det bedre (11), og ved å involvere deltakerne kan man komme langt i en utviklingsprosess. Om prosjektet har gyldighet, handler om avdekkede fenomen som kan overføres til en annen kontekst (18). Vi mener at deltakermedvirkning kan benyttes i sammenhenger der det er et ønske om å forbedre noe. Når deltakerne blir hørt og tatt på alvor, vil motivasjonen kunne øke, enten de er helsepersonell eller brukere av helsetjenester. sØT-modellen (13) og logg vil kunne være gode verktøy.

\section{Konklusjon}


Deltakermedvirkning har økt motivasjonen til å delta på undervisning og samhandlingstrening ved RSA. Ved at deltakernes ønsker og behov hele tiden er i fokus, blir handlingsmuligheter og videreutvikling kontinuerlig vektlagt, og prosjektet har derfor ingen tydelig slutt. Det vil alltid være mulig å forbedre praksis, og undervisningsgruppa fortsetter å justere undervisningen etter deltakernes ønsker og behov.

\section{Referanser}

1. Oslo universitetssykehus. Medisinsk simulering, Psykisk Helse og Avhengighet. Oslo: Oslo universitetssykehus; 2012. Tilgjengelig fra: http://www.simoslo.no/pha (nedlastet 24.05.2018).

2. Lov 17. juni 2005 om krav til det psykososiale arbeidsmiljøet (arbeidsmiljøloven). Tilgjengelig fra: https://lovdata.no/dokument/NL/lov/2005-06-1762/KAPITTEL_5\#§4-3 (nedlastet 24.05.2018).

3. Lillevik OG, Øien L. Miljøterapeutisk arbeid i møte med vold og aggresjon Oslo: Gyldendal Norsk Forlag; 2014.

4. Vaage S. Perspektivtaking, rekonstruksjon av erfaring og kreative læringsprosesser. I: Dysthe O, red. Dialog, samspel og læring. Oslo: Abstract forlag; 2001. s.130.

5. Wenger E. Communities of Practice. Learning, Meaning and Identity. Cambridge: Cambridge University Press; 1998.

6. Benner P. Fra novice til ekspert. Mesterlighed og styrke i klinisk sygeplejepraksis. København:

Munksgaard; 2004.

7. Grendstad NM. Å lære er å oppdage. 7. utg. Oslo:

Didakta Norsk Forlag; 1986. s. 17-25. 
8. Spetalen H. Voksenpedagogikk og opplæring i arbeidslivet. Lillestrøm: Høgskolen i Akershus, Småskrift; 1/2007.

9. Freire P. De undertryktes pedagogikk. 2. utg. Oslo: Gyldendal Akademisk; 1999.

10. NIFU, Nordisk institutt for studier av innovasjon, forskning og utdanning [internett]. Oslo: NIFU; 2015 [sitert 03.01.2019]. Tilgjengelig fra: https://www.nifu.no/fou-statistiske/fou-statistikk/om$\underline{\text { fou/definisjoner-og-klassifiseringer/ }}$

11. Whitehead J, McNiff J. Action research living theory. London: SAGE Publications; 2006.

12. Gadamer HG. Truth and method. 4. utg. London: Continuum; 2004.

13. Hartviksen M, Kversøy KS. Samarbeid og konflikt: to sider av samme sak. Bergen:

Fagbokforlaget; 2008.

14. Dewey J. Democracy and education. Middelsex: The Echo Library; 2007.

15. McKenzie B. Systemic leadership [internett]. Australia: Center for Systemic Leadership [sitert 02.01.2019]. Tilgjengelig fra: http://centerforsystemicleadership.com/?page_id=9

16. Kversøy K. Metodeeksperimenter med radikal medvirkning i utdanning og forskning. (Doktoravhandling.) Oslo: Høgskolen i Oslo og Akershus; 2015.

17. Charmaz K. Constructing grounded theory, a practical guide through qualitative analysis. London: SAGE Publication; 2012.

18. Sannerud AR. Interaktiv forskning. Lillestrøm: Høgskolen i Akershus, Småskrift; 1/2003. 
19. Kvale S. Det kvalitative forskningsintervju. Oslo:

Gyldendal Norsk Forlag; 2001. 